\title{
Women in Patriarchal Society ---- \\ Heroine Image Interpretation in Long Day's Journey into Night
}

\author{
Li jing \\ Wuhan business school Wuhan, Hubei 430056 China
}

\begin{abstract}
Eugene O Neill is one of the most famous playwrights in the 20th century. In his plays, he depicted multiple women images, and among them, heroine Mary's image is the most typical in drama Long Day's Journey into Night, which is the known representative masterpiece of Eugene O Neill. From Mary's three social roles: daughter, wife and mother, this paper respectively interprets the images of Mary in the drama.
\end{abstract}

Key words: Patriarchal society; Women; Image interpretation; Realism

Eugene O Neill is the founder of the twentieth century American serious drama. His plays often adopt the style of realism, reflect profound problems of capitalist society, and express the author's view in the drama creation on these problems. Eugene $\mathrm{O}$ Neill is good at absorbing the advantages of various factions' drama creation, and uses various methods to compose. His plays have a unique style. In drama creation, Eugene $\mathrm{O}$ Neill tends to perfectly combine realism and modern expression techniques, which make his drama productions having richer characteristics. At the same time, Eugene O Neill's play creation comes from daily life of ordinary citizens, and shows the general public perception and attitude of life. He describes the characteristics and the process of split personality of the people living in the bottom of the society, often with strong tragic color. Since the creation of Eugene O Neill is close to ordinary people's life, it is simple, which has become the symbol of American culture. Eugene O Neill has a pivotal position in the history of American literature.

Long Day's Journey into Night is Eugene O Neill's autobiographical drama creation in the $1940 \mathrm{~s}$. In the drama, Eugene O Neill takes the heroine Mary's tragic life experience as the clue, and shows the family members' emotional change toward heroine Mary. He profoundly analyzed the root of the misfortune of Mary in the family: patriarchal society's oppression on women. And he analyzed the profound social root. Through drama Long Day's Journey into Night, the author reveals the ugly phenomena of capitalist society, and the author's hate and helpless on this phenomenon, as if the author was looking for something in Long Day's Journey into Night, but was still in searching after arduous journey, which gives readers thinking and dismay space. This probably is the unique and charm of Eugene O Neill. In the drama Long Day's Journey into Night, although the author Eugene O Neill exposed and analyzed various social problems, the author mostly adopted idealistic and mysterious ways with rich pessimistic color. Often there was no right way to solve these problems, and because of this, Eugene O Neill's drama creations appear more pessimistic.

At present, literary critics hold different ideas for the heroine Mary in Long Day's Journey into Night. Some people say that she is sympathetic, and some people say that she is the cause of family difficulties. Her behavior not only brings suffering and distress to the family but brings torment to herself. She is the most despicable and tiresome woman, and is not worth the sympathy of the readers. But I believe these comments only see the surface of the heroine image in the play, Mary, and have no in-depth discussion and analysis on the problem, which also fails to seize the essential content of heroine Mary's image. In patriarchal society at that time, heroine Mary was not subject to the oppression and rule of man, and made helpless and negative resistance to the rule and oppression. The traditional moral standard governed Mary's thought, plus too strong patriarchal power. As a woman, Mary finally made no escape from the control of male chauvinism. From the triple life roles of heroine Mary: daughter, wife, and mother, specific analysis on the image of Mary in patriarchal society is carried out below. 


\section{THE IMAGE OF HEROINE MARY AS A DAUGHTER}

Teenager heroine Mary was happy. She grew up in a family with certain identity and status, received a good education, and lived a carefree life. As the daughter, Mary had pious belief in God, and her dream was to be a nun or a pianist. Her father was agreeable to Mary, and her family was affectionately to her. Heroine Mary had harmonious relationship with classmates. As a teenager, Mary was pure and perfect, and she was healthy and lively, full of sunshine.

One French writer analysis said that "woman is not born, but is gradually formed". This view can cleverly and brilliantly sum up the growth process of a woman. Born family is the first place for a woman. She grows up in the place, and parents tend to adopt different standards to their children's education and cultivation. For their children, parents raise requirements to them, such as brave and strong, independent personality, gentle, intelligent and so on. And heroine Mary was not exceptional, she began to accept the influence of patriarchal society since born, and her fate got patriarchal control. Her father completely shaped and cultivated Mary in accordance with the patriarchal way, which determined that heroine Mary cannot have free room to grow and inevitably became the victim of the society. Pianist and nun were the teenager Mary's two big dreams. Young heroine Mary's dream was to be a nun monastery, which shows the deep influence of the patriarchal society on Mary.

\section{THE IMAGE OF HEROINE MARY AS A WIFE}

Young heroine Mary gradually lost emotional sustenance in the boring monastery life. Heroine Mary has not completely given up the secular concept. On the one hand, heroine Mary looked for positive emotion reposing, but on the one hand, she dedicated to religious cause without any aims. These two aspects caused great suffering to young heroine Mary. For a good marriage life desire and thirst for emotional sustenance, heroine Mary fell in love with actor Tyrone. In patriarchal society, for girl Mary, the meaning of marriage is to have a warm home and a husband who can keep rain away. Also heroine Mary should shoulder the responsibility of bearing children and to be a good wife and mother. These are all set roles for heroine Mary in patriarchal society. But for heroine Mary, it seems unlikely because she now has a happy family, and there are relatives who love her and spoil her. She now lives carefree life, and she worries about these nice things will go away after the marriage. But out of desire for a good marriage life, heroine Mary marries to actress Tyrone. But married life is not as easy as Mary thought but gives her a lot of hardships. After marriage, Tyrone drifts around, and Mary endures long depressed and lonely life. Her husband is mean on money which also let heroine Mary unbearable. Her husband Tyrone asked an unqualified doctor use morphine for Mary when she was giving birth to a child in order to save money. Then Mary began addicted to drug.

After marriage, heroine Mary found that life was not as good as she had imagined, and she felt deeply disappointed. Depressed Mary cut off childhood playmates and can't get along with the people around her. After marriage, Mary was in isolated predicament, and she was very anxious to get rid of this trouble. However, because she was deeply influenced by the whole society since childhood, heroine Mary formed the psychology of roll with the punches. Mary's resistance ability and live ability were very low, which also come from the influence of patriarchal society and control. As a result, heroine Mary began to recall the happy time when she was a child, and took morphine to get comfort and ease her inner anguish. From this perspective, heroine Mary was a failure and also painful as a wife. But heroine Mary's failure and pain was not personal. The combination of the factors: Mary's father's education approach, the two families, and patriarchal society leads to the tragedy of heroine Mary's marriage.

\section{THE IMAGE OF HEROINE MARY AS A MOTHER}

After marriage, heroine Mary still did not find her own emotions and remained depressed. After birth, the child was cultivated as the same in accordance with the traditional standard of patriarchal society at that time. Heroine Mary's being a good mother wish was eventually burst. The sons of heroine Mary grew up with a large amount of education of the ideas in patriarchal society, and female subordination ideas were in their souls. In dealing with their mother, heroine Mary, they often revealed despised attitude. And Mary's eldest son's performance was particularly strong. The eldest son grew up with Mary's love, and he was very attachment to his mother, but since the birth of his brother, the eldest son felt left out and alienation by his mother. In order to save the mother's love for him, he deliberately put the measles virus to his young brother, and finally caused the death of the brother. However, after his brother's death, mother Mary did not love him like before, but as the eldest son, he was more out in the 
cold. The eldest son then formed the bad habit of drinking like his father and eventually became a drunkard and tramp. In the heart of the eldest son, mother Mary was not so cordial as in the past and his heart was full of resentment of her mother.

For the little son, mother Mary seemed to pour all her soul and love, trying to play the role of a good mother and want to get returns from her youngest son. But the youngest son was always indifferent to his mother's concerns, which made heroine Mary feel more disappointed. The role of heroine Mary as a good mother was finally broken, and Mary finally was on the verge of collapse. On the way to be a good woman, heroine Mary completely lost the direction. So heroine Mary began to escape from her family and prayed to get a temporary relief with plenty of morphine. Although heroine Mary tried to revolt against patriarchal society's control, but in the end she did not throw off the shackles of patriarchal society. Heroine Mary's sadness is because she has quietly accepted her ideas and social identity imposed by patriarchal society. Heroine Mary's sorrow is not one person's sadness, but the sadness of all women in the patriarchal society.

\section{SUMMARY}

Mary, the tragic image of women, was shaped in Drama Long Day's Journey into Night. The discrimination against women in patriarchal society can be said to be the root of heroine Mary's life tragedy. Mary's life is affected by the control and influence of patriarchal society and had the tragedy color. After getting married, Mary's life tragedy is richer. Mary's life is to fight this unequal relationship between men and women, eager to live a happy life, but the in depth patriarchal society thought in her soul destined the failure of Mary's resistance.

\section{REFERENCE}

[1] Zhu Liping. Narrative, understanding, analysis and reflection ---- interpret heroine Mary’s image in Long Day’s Journey into Night [J]. Journal of Chifeng University Journal (Chinese Philosophy and Social Science Edition), 2011, 04(04) : 109-110.

[2] Zhou Ying. Female images and female consciousness evolution in the works of Eugene O Neill [J]. Journal of Brand (Second Half), 2014, 02 (03) : 78

[3] Zou Lulu. Long Day’s Journey into Night ---- playwright, novelist and poet Fuse [J]. Journal of Drama Art, 2014, 05 (5) : 9094.

[4] Tian Li. The importance of women with beautiful appearance under patriarchy society [J]. Foreign Language Teaching Research in Jiangsu, 2013, 02 (02) : 63-66.

[5] Xu Yinghui. Discrimination and oppression, fight and revolt---- the heroine Mary's character image analysis in Long Day's Journey into Night [J]. Journal of Jilin Institute of Education, 2011, 02 (03) : 129-131.

[6] Qin Lihua. Mary's tragedy root in Long Day's Journey into Night ---- alienation [J]. Journal of Anhui Technical College of Electronic Information, 2013, 03 (03) : 108-110 + 52.

[7] Zhou Qian. Analysis of the survival state of the hero in Long Day's Journey into Night [J]. Journal of Chinese Construction, 2013,06 (23) : 35-36.

[8] Lu Yuna. Mary's plump female images in Eugene O Neill’s Long Day's Journey into Night [J]. Journal of Xingyi Nationalities Normal College, 2012, 03 (3) : 56-58. 